\title{
Stwórcze działanie Bożego rûạ w Księdze Ezechiela
}

\section{The Creative Activity of God's rûa ${ }^{a}$ in the Book of Ezekiel}

\section{WOJCIECH PIKOR}

Uniwersytet Mikołaja Kopernika w Toruniu

wojciech.pikor@umk.pl, ORCID: 0000-0003-2656-152X

Streszczenie: Celem artykułu jest przybliżenie teologicznego znaczenia rûah w Księdze Ezechiela. Aktywność stwórcza Bożego ducha jest analizowana w opowiadaniu o powołaniu prorockim Ezechiela (Ez 1-3) oraz w wizji doliny wyschniętych kości (37,1-14). Wystąpienie tego samego wyrażenia rûhî („mój duch”) w 36,27; 37,14 i 39,29 potwierdza nie tylko charakter stwórczy Bożego ducha, ale również pozwala uznać go za hipostazę Boga. Wewnętrze odrodzenie dokonane przez ducha Jahwe czyni nie tylko z Ezechiela, ale również z Izraelitów manifestację obecności Boga w świecie.

Słowa kluczowe: Księga Ezechiela; duch Jahwe; pneumatologia; stworzenie; powołanie prorockie; wizja doliny wyschniętych kości

Abstract: The article aims to introduce the theological meaning of the rûa in the Book of Ezekiel. The creative activity of God's spirit is analyzed first in the prophetic call of Ezekiel (Ezek 1-3) and then in the vision of the Valley of Dry Bones (37:1-14). The same expression rûthî ("my spirit") in 36:27; 37:14 and 39:29 not only confirms the creative character of God's spirit, but reveals its status as a hypostasis of God. The inner renewal - possible through God's spirit - makes vital the manifestation of God on earth, not only to Ezekiel but also to the Israelites.

Keywords: book of Ezekiel, spirit of YHWH, pneumatology, creation, prophetic call, vision of the valley of dry bones

Wśród wielu elementów wyróżniających Księgę Ezechiela spośród innych tekstów Biblii Hebrajskiej można wskazać pięćdziesiąt dwa wystąpienia rzeczownikak rûaḥ, które skłaniają komentatorów do nazwania Ezechiela „prorokiem Ducha”. Znaczenie tego rzeczownika jest szerokie: od meteorologicznego („wiatr, podmuch”, pochodny sens „strony świata”) przez antropologiczne („oddech”, „tchnienie”, „siedlisko myśli, uczuć, „wewnętrzny impuls” w sensie woli) po teologiczne („duch Boży”). Granice między tymi różnymi znaczeniami semantycznymi są płynne, co sprawia, że interpretacja danego wystąpienia rûa $\hat{u}^{a} \mathrm{w}$ Księdze Ezechiela staje wobec wieloznaczności otwartej na kolejne relektury. O otwartości procesu interpretacyjnego terminu rû́h w Księdze Ezechiela świadczy rosnące w ostatnich dziesięcioleciach zainteresowanie

1 Block, „The Prophet of the Spirit”, 28. 
biblistów tą kwestią ${ }^{2}$ To, co pozostaje wciąż nie do końca zauważane, to relacja między osobistym doświadczeniem r $\hat{u}^{a} h ̣$ przez proroka Ezechiela w momencie powołania (Ez 1-3) a jego trzema proroctwami o darze rûa h, identyfikowanym jako duch Jahwe przez zwrot rûhîi („mój duch”) w 36,27; 37,14 i 39,29. Szczególnie interesująca jest paralela między działaniem $r \hat{u}^{a} h$ wobec Ezechiela podczas widzenia chwały Jahwe $(2,2)$ a działaniem wobec wyschniętych kości $(37,10)$ w wizji opisanej w 37,1-14. Jaka jest relacja między tymi wizjami: czy tylko formalna, czy też teologiczna, pozwalająca na pogłębienie rozumienia tożsamości rû̉ ${ }^{a} h$ ? Jaką rolę w życiu proroka, ale też i ludu przymierza odgrywa rû̉ $\hat{u}^{a}$ ? W jakim stopniu osobiste doświadczenie $r \hat{u}^{a} h$ przez Ezechiela miało wpływ na kształt wypowiadanych przez niego obietnic r $r \hat{u}^{a} h$ ? Analiza narracji o powołaniu Ezechiela (1-3) i wizji wyschniętych kości $(37,1-14)$ będzie miała na celu poszukiwanie odpowiedzi na powyższe pytania.

\section{Duch stwarzający proroka (Ez 2,2)}

Opowiadanie o powołaniu Ezechiela jest wyjątkowe na tle innych tego rodzaju narracji w Biblii Hebrajskiej. Łączy w sobie dwa typy opowiadań o powołaniu prorockim, sytuując je najpierw w kontekście widzenia chwały Jahwe (Ez 1), a następnie przedstawiając je jako wydarzenie słowa $(\text { Ez } 2-3)^{3}$. Powołanie Ezechiela jest rozciągnięte w czasie, inaczej niż w przypadku innych proroków, których powołanie jest przedstawiane jako wydarzenie punktowe. Po pierwszym spotkaniu chwały Jahwe $(1,4-3,15)$, siedem dni później (por. 3,16), Ezechiel zostaje ustanowiony jako „stróż nad domem Izraela" (3,16-21). Następnie, w bliżej nieokreślonym odstępie czasu, ponownie doświadcza spotkania chwały Jahwe (3,22-24a), w trakcie którego poznaje dalsze szczegóły swojej komunikacji prorockiej, tym razem niewerbalnej, bo związanej z przyszłym milczeniem $(3,24 b-27)$. Jedność retoryczna trzech pierwszych rozdziałów ${ }^{4}$ wynika nie tylko ze wspólnego tematu powołania prorockiego, ale również z inkluzji budowanej przez powtórzenie zdania opisującego bezpośrednie działanie $r \hat{u}^{a} h \underline{\mathrm{w}} \mathrm{w}$ stosunku do Ezechiela podczas widzenia chwały Jahwe: $r \hat{u}^{\mathrm{a}} \underline{h}$ „,wcho-

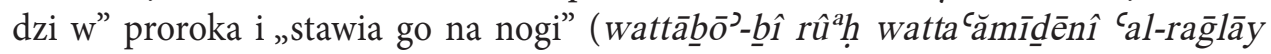

2 Wśród publikacji obejmujących całość wystąpień $r \hat{u}^{a} h \mathrm{w}$ K Księdze Ezechiela należy wspomnieć następujące artykuły: Block, „The Prophet of the Spirit”; Woodhouse, „The 'Spirit' in the Book of Ezekiel”; Kinlaw, „From Death to Life”; Hosch, „Rûah in the Book of Ezekiel”; oraz jedną monografię: Robson, Word and Spirit. Temat rî́a hest również przedmiotem odrębnych studiów w ramach analizy wizji wyschniętych kości w Ez 37: Wright, „The Concept of Ruach”; De Vries, „The Relationships”.

3 Zimmerli (Ezekiel I, 97-100) pierwszy typ narracji określa mianem „opowiadania o wizji”, wskazując na jego pierwowzór w powołaniu Izajasza (Iz 6), drugi nazywa „opowiadaniem o słowie”, przywołując powołanie Jeremiasza (Jr 1).

4 Pikor, La comunicazione profetica, 23-30. 
w 2,2; 3,24). W rezultacie narracja o powołaniu w Ez 1-3 może być odczytywana jako tekst programowy dla całej księgi, dając klucz do zrozumienia komunikacji prorockiej Ezechiela.

\subsection{Dynamika powołania Ezechiela}

O jakim rûa ḥ jest mowa podczas powołania Ezechiela? Dziesięć wystąpień tego terminu w opowiadaniu o pierwszym spotkaniu Ezechiela z chwałą Jahwe $(1,1-3,15)$ wymaga nie tylko zbadania ich znaczenia semantycznego, ale również uwzględnienia zachodzących między nimi pewnych różnic gramatycznych.

Ez 1 przynosi zapis widzenia chwały Jahwe, które Ezechiel miał w Babilonii nad kanałem Kebar w 593 r. przed Chr. (por. 1,1-3). Rzeczywiste opowiadanie o wizji zaczyna się w w. 4 od stereotypowego sformułowania "patrzyłem, a oto”, zaś kończy się wraz z ostatnim pojawieniem się czasownika „patrzeć” w w. 27, wprowadzającym ostatni szczegół wizji, po którym następuje w w. 28a konkluzja identyfikująca całość wizji: „To widzenie podobieństwa chwały Jahwe”. Wizja jest dynamiczna - przybliża się stopniowo do proroka, co umożliwia mu rejestrowanie wciąż nowych szczegółów.

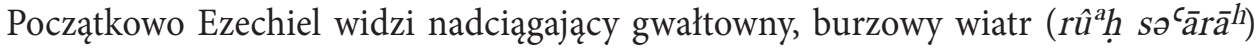
z północy (w. 4), w którym dostrzega cztery postaci „istot żyjących” (hayyôt, w. 5a). Stopniowo odsłania się przed nim ich wygląd - każda przypomina człowieka, ale mającego cztery twarze i dwie pary skrzydeł (ww. 5b-11). Istoty żyjące są w ruchu, co prorok intuicyjnie wiąże z prowadzącym je hārûa ḥ (w. 12). Można by sądzić, że początkowo ruch ma związek z towarzyszącymi widzeniu wyładowaniami atmosferycznymi (ww. 13-14), ale prorok przechodzi do opisu swoistego rydwanu, którego koła są usytuowane kolejno przy istotach żyjących (ww. 15-21). Źródłem mobilności nie są jednak koła, lecz hārûa ḥ (w. 20[x2]), dookreślony jako „duchu życia [rûa ḥ hahayy $\left.\bar{a}^{h}\right]$ w kołach" (ww. 20.21). Potwierdza to następujący dalej zapis efektów dźwiękowych towarzyszących rydwanowi w ruchu (ww. 22-25). Prorok zamyka swoją relację opisem postaci dosiadającej rydwanu (ww. 22-28a), jakkolwiek, podobnie jak w przypadku wcześniejszych szczegółów widzenia, jest to tylko próba przybliżenia jej podobieństwa do człowieka.

Reakcją Ezechiela na widzenie chwały Jahwe jest prostracja na ziemię (w. 28b), która wyklucza możliwość komunikacji, na co wskazuje polecenie powstania na nogi, jakie kieruje do niego głos dochodzący od rydwanu $(2,1)$. Ta zmiana pozycji następuje dzięki r $\hat{u}^{a} h$, który - jak już to zostało wspomniane - „wchodzi w niego i stawia go na nogi” (w. 2). Identyczna sekwencja zdarzeń w widzeniu chwały Jahwe, mającym miejsce jakiś czas później na równinie (prostracja wobec chwały Jahwe; wejście rûa ḥ w proroka; postawienie na nogi [3,23b-24]), pozwala sądzić, iż to działanie rûa $\hat{u}^{a}$ ma znaczenie paradygmatyczne dla komunikacji prorockiej. W obu przypadkach następuje dalej słowo, w którym Bóg definiuje Ezechiela jako proroka. Pierwsze widzenie powołaniowe kończy się odejściem chwały Jahwe (3,12-13), czemu towarzyszy 
działanie rûa ḥ wobec Ezechiela: „podnosi go" (rûa ḥ jako podmiot czasownika nāśáa w ww. 12.14) i „zabiera” (lāqạ̣ w w. 14). Nie jest to już doświadczenie wizyjne, gdyż powstawszy, prorok powraca znad kanału Kebar do wygnańców w Tell-Abib, targany w swoim wnętrzu (rûḥ̂̂) różnymi emocjami (w. 14).

\subsection{Tożsamość rûạ̣ w widzeniu chwały Jahwe (Ez 1)}

Przedstawiona w skrótowy sposób dynamika widzenia zapisanego w Ez 1-3 pozwala zauważyć, iż jednym z elementów kluczowych dla interpretacji doświadczenia przez Ezechiela chwały Jahwe jest $r \hat{u}^{a} h^{5}$. Daniel I. Block stwierdza, że

nie jest jasne powiązanie między [poszczególnymi rû̉ ḥ wzmiankowanymi w widzeniu:] rû̉ $h$ obecnym w kołach, poruszającym istoty żywe $(1,12.20 .21), r \hat{u}^{a} h$ przynoszącym burzę, z którego rodzi się wizja proroka $(1,4)$, dalej rûa ḥ, który później wchodzi w niego i go pobudza $(2,2 ; 3,24)$, i wreszcie rû́a h, który na końcu go podnosi i wyprowadza $(3,12.14)$. Jednakże te odniesienia zapowiadają rolę, jaką odegra $r \hat{u}^{a} h \underline{h} \mathrm{w}$ posłudze Ezechiela ${ }^{6}$.

Jeśli nie ma wątpliwości wśród egzegetów co do identyfikacji rûa ḥ w 1,4 jako wiatru, to już w przypadku użycia tego terminu w 1,12.20.21, dla wskazania źródła ruchu istot żyjących (rydwanu), pojawiają się różne opinie. Nie wszyscy też zwracają uwagę na pewne zmiany gramatyczne w tych wersetach: jeśli w w. 4 rû̉ $\hat{u}^{a}$ występuje bez rodzajnika jako rzeczownik rodzaju żeńskiego, to w ww. 12.20 jest już rzeczownikiem określonym rodzaju męskiego, wchodząc $\mathrm{w}$ związek przydawkowy $r \hat{u}^{a} h \underline{h}$ hahayyā $\bar{a}^{h} \mathrm{w}$ ww. 20.21. W przypadku tej syntagmy pojawia się jej tłumaczenie jako "duch istot żyjących", jednakże taki przekład wymagałby zmiany nomen rectum z liczby pojedynczej na mnogą (haḥayyôt). Lekcję TM wspierają starożytne przekłady (LXX: $\pi v \varepsilon \tilde{u} \mu \alpha \zeta \omega \tilde{\eta} \varsigma$; Wulg: spiritus vitae). Gdyby przyjąć, że rûa ha ożywiający koła pochodzi od istot żywych, to byłby to jedyny przypadek w Biblii Hebrajskiej, w którym źródłem ożywiającego „tchnienia życia” nie jest Jahwe ${ }^{8}$. Poza tym istoty żyjące pełnią funkcję służebną wobec tronu, co wyklucza, uwzględniając monoteizm właściwy Biblii Hebrajskiej, by mogły one stanowić jakiś podmiot rywalizujący z Jahwe. Przyjmując zatem tłumaczenie wyrażenia rû̉ $\hat{u}^{a}$ hahayyyă $\bar{a}^{h}$ jako „tchnienie/

5 Analiza retoryczna widzenia chwały Jahwe w Ez 1, odwołująca się do metodologii wypracowanej przez Rolanda Meynet, pozwala na wskazanie trzech elementów kluczowych dla Ezechielowej wizji chwały Jahwe: „ognia” wskazującego na transcendencję Boga, rûa ḥ objawiającego immanencję Boga i „głosu” świadczącego o relacji osobowej Boga z człowiekiem (por. Pikor, „Retoryka Ezechielowej wizji”, szczególnie 132-145).

6 Block, The Book of Ezekiel. Chapters 1-24, 101.

7 Zimmerli, Ezekiel I, 87; Allen, Ezekiel 1-19, 3; Greenberg, Ezekiel 1-20, 48; Joyce, Ezekiel, 71.

8 Następująca dalej argumentacja przywołuje niektóre z argumentów wysuniętych przez Robson, Word and Spirit, 88. 
duch życia”, pozostaje zapytać o sens określenia go wcześniej (w ww. 12.20) mianem samego hārûa h.

Dla części komentatorów poprzedzenie r $\hat{u}^{a} h ̣$ rodzajnikiem w w. 12 ma charakter anaforyczny i przywołuje $r \hat{u}^{a} h \underline{-}$ - wiatr, wprowadzony w w. $4^{9}$. Jednakże za rozpoznaniem w tych dwóch miejscach różnych znaczeń przemawia użycie rzeczownika rû $\hat{u}^{a} h \mathrm{w}$ innym rodzaju: $\mathrm{w}$ w. 4 , będąc podmiotem czasownika $b \bar{a}^{\jmath} \bar{a}^{h}, r \hat{u}^{a} h \underline{h}$ jest rodzaju żeńskiego, natomiast w w. 12 (podobnie w ww. 20.21), jako podmiot czasownika yihye $^{h}$, hārû́h $\hat{h}^{a}$ jest rodzaju męskiego ${ }^{10}$. Przyjmując dwa różne desygnaty terminu rûah, rodzajnik dookreślający ten rzeczownik w w. 12 może kataforycznie odsyłać do późniejszego wystąpienia tego terminu w ww. 20.21, w których jest on przedstawiony nie jako wiatr, lecz siła wprawiająca w ruch istoty żywe. Dzięki temu rû́ạ „normalnie nieożywione przedmioty wydają się prorokowi żywe tak jak same «istoty żyjące». To ten ożywiający duch determinował kierunek i swobodę ruchu niebiańskiego rydwanu" "'. Źródłem tego impulsu, animującego istoty żyjące, może być tylko Jahwe. Niektórzy egzegeci, akcentując bardziej wpływ owego rü $\hat{u}^{a} h$ na kierunek ruchu istot żyjących (ww. 12.20), utożsamiają r $\hat{u}^{a} h \mathrm{~h}$ z wolą Bożą działającą w istotach żyjących ${ }^{12}$.

Łącząc cały czas hārûa ḥ z ww. 12.20.[21] z osobą Jahwe, jeszcze inną interpretację proponuje James Robson ${ }^{13}$. Zakłada on, iż rodzajnik sygnalizuje w tym wypadku „rzeczownik już określony w wyobraźni, który odnosi się do szczególnej osoby lub rzeczy rozumianej jako już obecnej albo też przedstawia kogoś lub coś, którego tożsamości nie da się inaczej wskazać" ${ }^{14}$. Dalej zauważa, że w kilku tekstach Biblii Hebrajskiej r $\hat{u}^{a} h$ q zyskuje szersze znaczenie niż tylko „duch Jahwe”. W Ps 51,13; 139,7 oraz w Iz 63,10-14 jego synonimem jest termin Pänîm („twarz, oblicze”), wyrażający obecność Jahwe w świecie. Podobne znaczenie przyjmowałby rzeczownik r $\hat{u}^{a} h \mathrm{~h} \mathrm{w}$ analizowanej wizji ${ }^{15}$. Byłaby to ta sama obecność Jahwe, która manifestowała się podczas exodusu w słupie ognia. W tym kontekście możliwe jest mówienie o podmiotowości

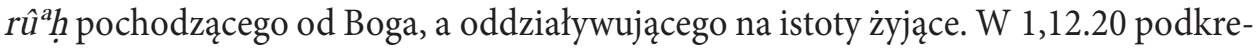

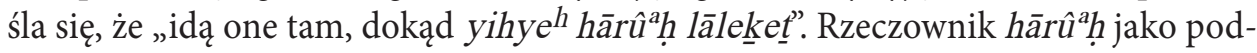

9 Sedlmeier, Das Buch Ezechiel. Kapitel 1-24, 84; Woodhouse, „The 'Spirit”, 9.

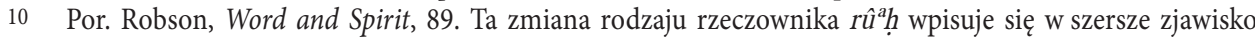
pomieszania rodzajów rzeczowników (przede wszystkim haHayyôt) w Księdze Ezechiela. Zimmerli (Ezekiel II, 566) interpretuje to jako wynik błędów popełnionych przez późniejszych redaktorów narracji, jakkolwiek tego rodzaju błędy, związane z pomyleniem pojedynczej litery w sufiksie, można tłumaczyć pomyłkami skrybów (por. Eichrod, Ezekiel, 55-56). W przypadku „istot żyjących” egzegeci zauważają ponadto, iż w ikonografii starożytnego Bliskiego Wschodu byty te są przedstawiane raz jako postaci męskie, innym razem jako żeńskie, co mogło skutkować myleniem rodzaju rzeczownika będącego ich nazwą (por. Hiebel, Ezekiel's Vision, 60-61).

11 Block, The Book of Ezekiel. Chapters 1-24, 101.

12 Zimmerli, Ezekiel I, 566; Allen, Ezekiel 1-19, 32; Eichrod, Ezekiel, 57.

13 Robson, Word and Spirit, 90-91.

14 Robson (Word and Spirit) cytuje w tym wypadku Waltke - O’Connor, An Introduction, \$13.5.1e.

15 Robson, Word and Spirit, 91. 
miot czynności wyrażonej czasownikiem „iść”, a za chwilę, gdy będzie działał wobec Ezechiela, czasownika „wejść”, może być postrzegany jako hipostaza Boga. W tym wypadku przez hipostazę Boga rozumie się pewną Jego jakość, atrybut czy manifestację, które przez proces personifikacji i różnicowania stały się istotą od Niego różną ${ }^{16}$. Przypadłościowo r $\hat{u}^{a} h$ jako hipostaza będzie odmienny w swoim działaniu od Jahwe, jednakże to działanie będzie cały czas działaniem samego Jahwe, jako że r $r \hat{u}^{a} h \underline{\text { p pocho- }}$ dzi od Niego, uobecnia Jego ożywającą moc i pozostaje wyrazem Jego woli.

\subsection{Duch Jahwe a powołanie proroka Ezechiela (Ez 2,2)}

Przedmiotem działania rûa ḥ jest również Ezechiel, który rozpoznając w widzeniu rzeczywistość chwały Jahwe, pada na ziemię $(1,28)$. Jego powstanie dokonuje się mocą rûa ḥ, który „wszedł w niego" i „postawił go na nogi” (2,2). Rzeczownik rüạ nie jest tu poprzedzony rodzajnikiem, co mogłoby sugerować, iż działający wobec proroka $r \hat{u}^{a} h$ jest różny od tego animującego istoty żyjące. Keith Carley widzi tu działanie „wiatru”, podobnie jak w 3,14, kiedy to, na zakończenie widzenia, r $\hat{u}^{a} h$, „podnosi

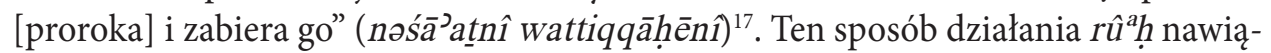
zywałby do przedklasycznej tradycji prorockiej, znanej przede wszystkim z opowiadań o Eliaszu ${ }^{18}$. Można zgodzić się, iż w Ez 2,2 ma miejsce nawiązanie do tej tradycji, co tłumaczyłoby pominięcie rodzajnika przy rzeczowniku rû́ $\hat{a ̣}^{19}$. Zauważa się jednak pewne różnice między Ez 2,2 i tradycją o Eliaszu, które skłaniają do identyfikacji

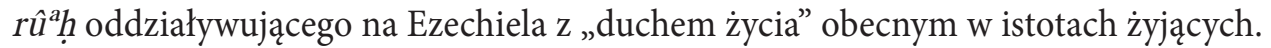
Zarówno w przypadku Ezechiela, jak i istot żyjących, $r \hat{u}^{a} h$, w przeciwieństwie do tradycyjnych obrazów, nie działa od zewnątrz, jak podmuch wiatru, lecz od wewnątrz podmiotu, z którym się jednoczy. Nie chodzi przy tym tylko o impuls potrzebny do podjęcia czy pokonania jakiejś drogi. Ezechiel, nazywany konsekwentnie przez Boga ben- ’ādām - „synem człowieczym”, czyli śmiertelnikiem, kimś zmierzającym ku śmierci (por. 31,14), wobec chwały Jahwe pada na ziemię ${ }^{20}$. Skierowane do niego polecenie: „Stań na nogi, bym mógł mówić z tobą” $(2,2)$, ujawnia intencję komunikacyjną Boga, który chce uzdolnić Ezechiela do dialogu z sobą, by móc go posłać jako proroka do domu Izraela. Leżąc na ziemi, Ezechiel jest w istocie bez życia. $r \hat{u}^{a} h ̣$, który wchodzi w niego, okazuje się być życiodajną siłą Jahwe, która ożywia go,

16 Por. definicję hipostazy S. Dean McBridge w: Strong, „God’s Kābôd”, 72; Yadin, „qôl as Hypostasis”, 3-4.

17 Carley, Ezekiel Among the Prophets, 30.

18 W opowiadaniach o Eliaszu mówi się jednak tylko o możliwości, iż „Duch Jahwe podniesie” proroka (1 Krl 18,12; $2 \mathrm{Krl} 2,16)$ i go „zabierze” (2 Krl 2,3.5).

19 Allen, Ezekiel 1-19, 38. Podobny brak rodzajnika widzi się w pozostałych wystąpieniach rự $\hat{u}^{a}$ w Księdze Ezechiela, kiedy jest mowa o przemieszczaniu się proroka pod wpływem „ducha” (3,12.14.24; 8,3; 11,1.24; 43,5). Bliskiego Wschodu jako gest rozpoznania i uznania Jahwe jako króla (por. Block, The Book of Ezekiel. Chapters 1-24, 115). 
a w istocie stwarza jako proroka, czyniąc go zdolnym do wejścia w relację z Bogiem za pośrednictwem słowa. $r \hat{u}^{a} h$ pozostaje nierozerwalnie związany ze słowem stanowiącym przedmiot komunikacji między Bogiem i prorokiem, a w konsekwencji ze słowem, które prorok będzie dalej głosił ludowi. Składnia analizowanego w. 2 pozwala na stwierdzenie, iż $r \hat{u}^{a} h \underline{h}$ wchodzi w Ezechiela w tym samym momencie, w którym Bóg wypowiada polecenie powstania ${ }^{21}$. Ten $r \hat{u}^{a} h$ sprawia, że Ezechiel może „słuchać tego, który mówił do niego ( 'êt middabbēr 'ēlāy)". Słowo Boga, w świetle użycia tu rzadkiej formy Hitpael czasownika „mówić”, ma charakter dialogiczny. Koniugacja Hitpael pozwala na interpretację „mówienia” Boga nie jako komunikacji jednostronnej (monolog), lecz jako dwustronnej (dialog), w której uczestniczą oba podmio-

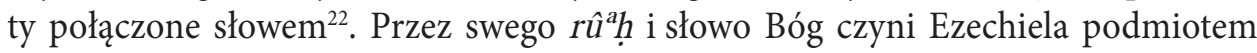
w swojej komunikacji, zawiązując z nim relację międzyosobową.

Obecność Bożego rûa ḥ w Ezechielu nie kończy się wraz z zakończeniem widzenia chwały Jahwe. Czasowniki nāśẫ’ („podnieść” w 3,12.14) i lāqạ̣ („zabrać” w 3,14) ponownie nawiązują do konwencji językowej charakterystycznej dla opowiadań o Eliaszu, sugerując rozumienie jako podmuchu wiatru. Jednakże w tradycji o Eliaszu mowa jest tylko o możliwości takiego działania r $\hat{u}^{a} h \underline{h}$ wobec proroka ${ }^{23}$, podczas gdy w przypadku Ezechiela - o realnym działaniu rûa h. W Ez 3,12.14 nie chodzi przy tym tylko o wrażenie przemieszczania się, którego Ezechiel będzie doświadczał pod wpływem Bożego rûa ḥ podczas późniejszych wizji (por. 8,3; 11,1.24; $43,5)^{24}$. rû̉ ḥ, który wstąpił w Ezechiela podczas spotkania z chwałą Jahwe, nie opuścił go i prowadzi go, niczym wewnętrzny impuls, do wygnańców w Tell-Abib, wśród których ma podjąć powierzoną mu misję prorocką. Nie znaczy to, że Ezechiel jest pozbawiony własnego rûặ, gdyż idzie bahămat rûḥ̂ - „poruszony swoim duchem” $(3,14)$. Dochodzi do swoistej synergii między rǘạ Boga i rû́a $\hat{u}^{a}$ proroka. Nie chodzi tylko o ruch. Użyte w tej syntagmie nomen rectum (rûhîi) przyjmuje jakość nomen regens $\left(h \bar{e} \bar{e} \bar{a}^{h}\right)^{25}$. W Księdze Ezechiela rzeczownik ḥēm $\bar{a}^{h}$ - „gniew, wzburzenie, poruszenie" - na trzydzieści trzy swoje wystąpienia, aż trzydzieści jeden razy odnosi się do gniewu Boga w kontekście jego działania sądowniczego i karzącego ${ }^{26}$. Jeśli

21 Kluczową sprawą jest interpretacja spójnika Ka'ášer koordynującego dwa zdania w Ez 2,2: wattāḅō $\underline{\jmath} \hat{1}$ rụ̂̉̆ ka ăšer dibber 'ēlay. W Biblii Hebrajskiej, gdy w zdaniu złożonym dwie czynności są równoczesne, używa się spójnika ka’ăšser (por. Joüon - Muraoka, A Grammar, \$ 166n; Waltke - O’Connor, An Introduction, $\$ 38.7 \mathrm{a})$.

22 Interpretacja Hitpael za Waltke - O’Connor, An Introduction, $\$ 26.2 \mathrm{~g}$. Por. dyskusję nad trzema jedynymi wystąpieniami czasownika Däbar w Hitpael Biblii Hebrajskiej (Lb 7,89; Ez 2,2; 43,6) w: Pikor, „Retoryka Ezechielowej wizji", 143-144.

23 Por. przyp. 18.

24 Por. Pikor, La comunicazione profetica, 144.

25 Por. Waltke - O’Connor, An Introduction, $\$ 9.5 .1 \mathrm{j}$.

26 Por. Ez 5,13.15; 6,12; 7,8 itd. Tylko dwa razy mówi się o ludzkim „gniewie”: w 3,14 - Ezechiela, zaś w 23,25 - obcych narodów, jakkolwiek w tym przypadku „gniew” jest bardziej zapisem ich okrucieństwa wobec personifikowanej Jerozolimy, przez które działa qin’āa („zapalczywość) Jahwe. 
uwzględnić słowo, które Bóg przekazał Ezechielowi podczas powołania, także za pośrednictwem widzenia zwoju zapisanego $\mathrm{z}$ dwóch stron „narzekaniami, wzdychaniami i biadaniami" $(2,10)^{27}$, wówczas stan wewnętrzny Ezechiela, zapisany syntagmą bahămat rûḥ̂, koresponduje z myślami i uczuciami, jakie Bóg ma wobec swego ludu przymierza.

Działający w Ezechielu rûa ha jest identyczny z tym, który animuje ruch istot żyjących. Nie chodzi jednak tylko o siłę motoryczną, lecz o działanie ożywiające, wręcz stwórcze, co jest udziałem Ezechiela jako proroka. Podobne działanie powróci w wizji doliny pełnej wyschniętych kości (37,1-14).

\section{Duch stwarzający lud przymierza $(E z 37,14)$}

W porównaniu z innymi rozdziałami Księgi Ezechiela liczba dziesięciu wystąpień terminu rûa $\hat{a}_{\mathrm{w}} \mathrm{E}$ Ez 37 jest najwyższą w księdze. W analizowanym wcześniej Ez 1 termin powraca sześć razy, zaś w całej narracji o powołaniu (Ez 1-3) - jedenaście razy. W istocie w Ez 37 obecność rzeczownika rûa hamyka się w opowiadaniu o wizji wyschniętych kości $(37,1-14)$, co jeszcze bardziej podkreśla znaczenie tej narracji dla interpretacji Ezechielowego użycia rûa ḥ. Jeśli powołanie Ezechiela ma miejsce w 593 r. przed Chr., to wizja z Ez 37 rozgrywa się już po zdobyciu Jerozolimy przez Babilończyków w 586 r. przed Chr. (por. 33,21-22). To wydarzenie jest cezurą czasową, wyznaczającą w strukturze księgi początek nowej fazy aktywności prorockiej Ezechiela $^{28}$, w której na pierwsze miejsce wysuwają się wyrocznie zapowiadające przyszłe zbawienie Izraela. Niektórzy komentatorzy chcą odczytywać proroctwa znajdujące się w ostatniej części księgi jako zapis scenariusza przyszłego odrodzenia Izraela w perspektywie linearnie rozgrywającego się procesu zbawienia ${ }^{29}$ : po powrocie Izraela z wygnania (34-36) nastąpi ostateczne odrodzenie (zmartwychwstanie) Izraela (37), po którym dojdzie do ostatecznej bitwy z wojskami Goga - nieprzyjaciela z północy (38-39), co umożliwi powstanie ostatecznego królestwa Izraela (40-48). Przywołując typowy dla Księgi Ezechiela zabieg "przejmującej ekspozycji” (resumptive exposition), kiedy to pewne motywy wprowadzone wcześniej w księdze

27 Analiza zawartości tego zwoju w: Pikor, La comunicazione profetica, 108-111.

28 Nie chodzi jednak o przemianę Ezechiela z proroka kary w proroka zbawienia (pocieszenia), jak utrzymuje część komentatorów (por. Greenberg, Ezekiel 1-20, 3; Boadt, „The Function of the Salvation Oracles", 4-5; Joyce, Ezekiel, 42), gdyż wątki powołaniowe obecne w Ez 33, 1-20 potwierdzają status Ezechiela powołanego od początku na „stróża nad domem Izraela” (por. 3,16-21).

29 Por. Hals, Ezekiel, 230-231; Block, The Book of Ezekiel. Chapters 25-48, 271-272; Sedlmeier, Das Buch Ezechiel. Kapitel 25-48, 126-128. 
zostają podjęte i rozwinięte w nowych kontekstach ${ }^{30}$, wyrocznie z ostatniej części księgi należy interpretować komplementarnie, jako proroctwo przybliżające różne aspekty odrodzenia Izraela ${ }^{31}$. Dotyczy to również tekstów, w których zapowiada się przyszłe działanie r $\hat{u}^{a} h$. Odrodzenie Izraela przedstawionego metaforycznie jako wyschnięte kości, których powrót do życia, po przyobleczeniu w ciało, następuje przez ożywające je tchnienie Bożego rûạ $(37,14)$, stanowi wizualizację wcześniejszego proroctwa o nowym przymierzu, którego odnowienie dokona się nie tylko przez wymianę serca Izraela (z kamiennego na serce „z ciała”), ale również przez tchnienie w Izrael nowego, Bożego rûa potwierdzeniem i gwarantem trwałości odrodzenia Izraela, jako że obietnica wylania Bożego rûa ḥ na Izrael $(39,29)$ jest ostatnim zdaniem zamykającym wyrocznie zbawienia w Ez 34-39, po których następuje gatunkowo odmienne trzecie widzenie chwały Jahwe (40-48). Wymienione teksty 36,27; 37,14 i 39,29 razem przybliżają różne wymiary tego samego zbawczego działania Bożego ducha, identyfikowanego przez Boga jako rûhî („mój duch”).

\subsection{Dynamika wizji wyschniętych kości (Ez 37,1-14)}

Można odnieść wrażenie, że w komentarzach analiza kompozycji Ez 37,1-14 nie wzbudza większych problemów, inaczej niż kwestia jej literackiej spójności, która przekłada się na różne próby rekonstrukcji jej procesu redakcji ${ }^{32}$. W dyskusji nad spójnością tej narracji zwraca się uwagę przede wszystkim na dwie kwestie. Po pierwsze, brak pewnej koherencji między wizją (ww. 1-10) a jej wyjaśnieniem (ww. 11-14), co dotyczy przede wszystkim odmiennej metaforyki: w wizji mowa jest o dolinie, na powierzchni której zalegają wyschnięte kości (por. w. 2), natomiast w jej wyjaśnieniu pojawia się obraz grobów, zakładający, iż ciała (kości) zostały pogrzebane w ziemi (ww. 12.13). Po drugie, w samym wyjaśnieniu napotyka się na dwie interpretacje wcześniejszej wizji, które formalnie są oddzielone przez formułę poznania Jahwe, obramowującą drugą interpretację (ww. 13a.14b): pierwsze wyjaśnienie (w. 12) odczytuje wizję jako zapowiedź powrotu Izraela $\mathrm{z}$ wygnania do ziemi obiecanej, drugie (ww. 13-14) - przesuwa odrodzenie Izraela na czas po powrocie do ziemi obiecanej, w której dostąpi on daru Bożego rûa ḥ.

\footnotetext{
30 Pojęcie „przejmującej ekspozycji” w studiach nad Biblią Hebrajską wprowadził Michael Fishbane (Biblical Interpretation, 10-12), zaś obecność tego fenomenu retorycznego w Księdze Ezechiela wykazał Block, The Book of Ezekiel. Chapters 1-24, 24-25.

31 Por. Pikor, The Land of Israel, 116-119.

32 Syntetyczne omówienie różnych rozwiązań proponowanych w ramach krytyki redakcji Ez 37,1-14 w: Konkel, „The Vision of the Dry Bones”, 106-115.
} 
Przy podejściu synchronicznym wymienione rozbieżności nie są zasadniczo uwzględnienie w propozycjach schematycznego ujęcia struktury perykopy. Najczęściej proponuje się następujący schemat ${ }^{33}$ :

ww. 1-10 wizja

ww. 1-3 wprowadzenie - negatywna kondycja Izraela

ww. 4-8 pierwsze prorokowanie: „nad kościami”

ww. 9-10 drugie prorokowanie: „do hārûa ṭ"

ww. 11-14 wyjaśnienie

w. 11 przejście do interpretacji

ww. 12-14 wyrocznia zbawienia.

Część egzegetów ${ }^{34}$ proponuje podzielenie w. 11 na dwie oddzielne jednostki, z których pierwsza - w. 11a - stanowiłaby zakończenie wcześniejszej wizji, jako słowo wyjaśniające jej sens („Kości te to cały dom Izraela”), zaś druga - w. 11b - cytując pełną rozpaczy skargę Izraelitów („Wyschły kości nasze, znikła nasza nadzieja, jesteśmy zgubieni”), otwierałaby następujące dalej wyjaśnienie.

Niezależnie od pozycjonowania w. 11, panuje wśród komentatorów zgodna opinia, że przedstawiony w wizji dwufazowy proces ożywienia wyschniętych kości nawiązuje do dwóch etapów stworzenia człowieka w Rdz 2,735: Pan Bóg najpierw ulepił człowieka z prochu ziemi, a następnie „tchnął [yippah] w jego nozdrza tchnienie życia [nišmat hayyyîm]". W wizji Ezechiela kości najpierw obrastają ścięgnami, ciałem i skórą (Ez 37,7-8b), jednakże tak zrekonstruowanemu ciału brakuje rûa ḥ (w. 8b). Ożywienie zrekonstruowanych ciał następuje dopiero wraz z tchnieniem w nie $h \bar{a} r \hat{u}^{a} h^{36}$ (por. w. 9). W obu przypadkach stworzenie/odtworzenie ciała oddzielone jest od ożywienia je przez tchnienie pochodzące od Boga ${ }^{37}$.

Por. Allen, Ezekiel 20-48, 182-183; Block, The Book of Ezekiel. Chapters 1-24, 371-372; Sedlmeier, Das Buch Ezechiel. Kapitel 25-48, 209; Homerski, Ksiega Ezechiela, 255; Lemański, „Sprawisz, abym ożył”, 197; Zimmerli, Ezekiel II, 257; Greenberg, Ezekiel 1-20, 747-748; Hubmann, „Ezekiel 37,1-14”, 118.

Por. Hossfeld, Untersuchungen zu Komposition, 360-363; Graffy, A Prophet Confronts His People, 83; Fishbane, Biblical Interpretation,, 452; Hals, Ezekiel, 269.

35 Por. Zimmerli, Ezekiel II, 261; Fox, „The Rhetoric of Ezekiel's Vision”, 10; Greenberg, Ezekiel 21-37, 744; Wright, „The Concept of Ruach”, 154; Robson, Word and Spirit, 225-226; Granados García, La nueva alianza, 171-172; De Vreis, „The Relationship”, 336; Bossu, Une prophétie, 89.

Drugi etap, prowadzący do ożywienia kości, opisany jest kilkoma czasownikami, z którymi rûa ḥ wchodzi w związek znaczeniowy: Bóg „sprawi, że rûa ḥ wejdzie w nie” (czasownik bô w Hi + bo w w. 5); Bóg „da go w nie" (czasownik nātan w Qal + bo w w. 6); „rûa ḥ tchnie w nie” (czasownik nāpah + bo w w. 9); "hārûua $\underline{a}$ wchodzi w nie" (czasownik b $\hat{o}^{\supset}$ w Qal + bo w w. 10).

Oba teksty łączy czasownik nāpah („,tchnąć”; Rdz 2,7; Ez 37,9) oraz tchnienie ożywiające ciało. W tym wypadku w tekstach pojawiają się dwa różne terminy: w Rdz 2,7 mówi się o nišmat hayyyîm („tchnienie życia"), zaś w Ez 37 o rûa ḥ. Oba terminy określające tchnienie (oddech) występują w Biblii Hebrajskiej jako synonimy (por. Iz 42,5; Hi 34,14-15). W literaturze powygnaniowej $r \hat{u}^{a} h$ zdaje się zastępować nišmat (por. Koh 3,21; 12,7). Potwierdzeniem tego zjawiska byłoby występowanie zwrotu rûa ḥ hayyîm w Rdz 6,17; 7,15 - tekstach przypisywanych tradycji kapłańskiej. Być może pochodzenie kapłańskie Ezechiela tłumaczyłoby sięgnięcie przez niego po tę właśnie syntagmę. Por. Wright, „The Concept of Ruach”, 154; MacDonald, „The Spirit of YHWH”, 113. 
Podobną dwustopniowość zauważa się w wyjaśnieniu wizji w ww. 12-14. Zwolennicy podejścia diachronicznego ${ }^{38}$ zakładają, iż pierwotna interpretacja zamykała się w ww. 12-13a, w świetle których wyschnięte kości są metaforą Izraela na wygnaniu (por. 11a), zaś ich ożywienie - opisane metaforycznie jako wydobycie z grobu i przyprowadzenie do ziemi Izraela - zapowiadałoby w sposób metaforyczny nowy exodus. Pierwotne wyjaśnienie zostało później uzupełnione o ww. 13b-14: z jednej strony zauważa się powtórzenie dwóch pierwszych elementów pierwotnego wyjaśnienia w drugim (w. 12a $\beta$ = w. 13b: „otwieram wasze groby i wydobywam was z waszych grobów"), z drugiej strony pominięty trzeci element pierwotnego wyjaśnienia (w. 12b: „wprowadzę was do ziemi Izraela”) zostaje rozszerzony o w. 14, w którym Bóg zapowiada im dar „swojego ducha” (rûhîi) i „osadzanie ich na ich ziemi”. Pozostając jednak na płaszczyźnie synchronicznej ${ }^{39}$, obecne w ww. 12-14 powtórzenia (napięcia) można odczytywać jako przejaw charakterystycznego dla tekstów prorockich preferowania struktur (wypowiedzi) paralelnych, czego przykładem jest dwustopniowy proces ożywienia wyschniętych kości w wizji zrelacjonowanej w ww. 4-10. Przez analogię wyjaśnienie tej wizji zapowiadałoby odrodzenie Izraela $\mathrm{w}$ dwóch etapach: pierwszym byłby powrót $\mathrm{z}$ wygnania do ziemi Izraela (w. 12), zaś drugim - udzielenie Izraelitom daru Bożego ducha, dzięki któremu odrodzenie Izraela będzie w istocie nowym stworzeniem Izraela (w. 14).

Proponowana lektura dynamiki retorycznej Ez 37,1-14 wymaga dalszej weryfikacji przez podjęcie pytania o tożsamość $r \hat{u}^{a} h \underline{\mathrm{w}}$ tej narracji. Paralelna struktura wizji i jej interpretacji pozwala sądzić, iż kluczem do odpowiedzi będzie relacja między ww. 9-10 i w. 14.

\subsection{Teologiczne znaczenie rûaḥ w wizji wyschniętych kości}

Pamela Kinlaw postuluje odejście od statycznego postrzegania rûa ḥ w Księdze Ezechiela na rzecz koncepcji „rozwijającego się symbolu” (expanding symbol) ${ }^{40}$. Czytelnik w trakcie lektury proroctwa Ezechiela odkrywa wciąż nowe znaczenia $r u \hat{u}^{a} h$ przez konfrontowanie go z wcześniej poznanymi znaczeniami. W przypadku wizji wyschniętych kości możliwe jest odwołanie się przede wszystkim do doświadczenia $r \hat{u}$ ăh, jakie miał Ezechiel w momencie powołania. Jednakże dynamika ożywienia wyschniętych kości wskazuje na rozwinięcie teologicznego znaczenia rưh ha

Wprowadzenie narracyjne do wizji $(37,1)$ przywołuje nowy wymiar oddziaływania Bożego rû́h na proroka. Po pierwsze, jest on precyzyjnie określony przez wyra-

\footnotetext{
38 Por. Hossfeld, Untersuchungen zu Komposition, 382-388; Klein, Schriftauslegung im Ezechielbuch, 281-283; Konkel, „The Vision of the Dry Bones”, 113-115.

39 Dodać należy, że między zwolennikami podejście diachronicznego nie ma do końca zgody co do procesu redakcji Ez 37,11-14, por. inne propozycje w: Zimmerli, Ezekiel II, 257; Pohlmann, Der Prophet Hesekiel/ Ezekiel. Kapitel 20-48, 494-495.

40 Por. Kinlaw, „From Death to Life”, 162.
} 
żenie bərûa $h$ yhwh. Nie jest to konwencjonalne przywołanie rư $\hat{u}^{a} h$ jako siły motorycznej, podobnej w działaniu do podmuchu wiatru, który podnosi proroka. Podobne sformułowanie - bərû̉ḥ ’ělōhîm - pojawia się w 11,24 jako synonim wyrażenia bammar ${ }^{2} \mathrm{e}^{h}$ (,w widzeniu”), z którym pełni funkcję okolicznika sposobu dla zdania głównego: „rûặ podniósł mnie i zaprowadził do”. „Boży duch” uzdalnia zatem Ezechiela do otrzymania i przeżywania wizji, stając się narzędziem komunikacji prorockiej $^{41}$. Po drugie, w Ez 37,1, na opisanie komunikacji proroka za pośrednictwem wizji, zostaje użyta formuła „ręka Jahwe była nade mną”. W Księdze Ezechiela służy ona wyrażeniu przez proroka doświadczenia ekstatycznego, w trakcie którego słowo Boga jest mu komunikowane za pośrednictwem widzenia (por. 1,3; 3,22; 40,1) ${ }^{42}$. Po trzecie, Duch Jahwe jest zatem, trzymając się terminologii Blocka, „pośrednikiem natchnienia" prorockiego ${ }^{43}$. Tym samym doświadczenie inauguracyjne Ezechiela, w którym duch Jahwe „stwarza” go jako proroka, uzdalniając go do dialogu z Bogiem, jawi się zasadą komunikacji prorockiej (por. 11,5). Źródłem witalności Ezechiela jako proroka pozostaje duch Jahwe.

Nie znaczy to, że w wizji wyschniętych kości rûa h nie jest użyty w znaczeniu meteorologicznym. W istocie granice semantyczne $r \hat{u}^{a} h \mathrm{~h}$ tej wizji stają się płynne. W znaczeniu wiatru termin ten pojawia się w Ez 37,9, w którym prorok ma przywołać hārûa ḥ z 'arba' rûḥ̂t - wyrażenie to odnosi się albo do czterech stron świata, albo do wszystkich wiatrów wiejących na całym świecie ${ }^{44}$. Przywoływany hārûa ḥ z w. 9 nie jest jednak wiatrem, ale też nie jest tożsamy z rûaḥ, którego Bóg zapowiada (ww. 5.6) udzielić wyschniętym kościom, by ożyły. W tamtej zapowiedzi rûaḥ przyjmuje znaczenie tchnienia, oddechu, siły życiowej wspólnej wszystkim stworzeniom ${ }^{45}$, co też wynika z nawiązania do opisu stworzenia człowieka w Rdz 2,7. Odtworzone na bazie kości ciała pozostają jednak dalej bez rûa ḥ (Ez 37,8). Ich ożywienie dokona się dopiero dzięki hārûa ḥ (ww. 9-10), którego tożsamość można już zidentyfikować na podstawie wspomnianego mechanizmu "rozwijającego się symbolu”.

Po pierwsze, ożywiający ciała rûa $\hat{u}^{a}$ poprzedzony jest rodzajnikiem (hārû́ạ w ww. 9[x3].10). Identycznie dookreślony rû́a ha odgrywa kluczową rolę w animacji istot żyjących w wizji chwały Jahwe w Ez 1,12.20.21. Ten „duch życia” uosabia ożywiającą moc Boga, która teraz jest konieczna dla ożywienia zrekonstruowanych ciał.

41 Por. Greenberg, Ezekiel 21-37, 742.

42 Por. Pikor, La comunicazione profetica, 152.

43 Nie można jednak zgodzić się z Blockiem („The Prophet of the Spirit”, 34), który w swojej klasyfikacji poszczególnych wystąpień rûa ḥ w Księdze Ezechiela uznaje oba wyrażenia z 11,24 i 37,1 za fenomen meteorologiczny, interpretując rûa ḥ jako „wiatr kontrolowany bezpośrednio przez Boga”. Takiemu rozumieniu, jak zostało to wykazane wyżej, sprzeciwia się wyraźny kontekst komunikacji prorockiej sygnalizowanych w 11,24 i 37,1 (por. Allen, Ezekiel 1-19, 166; Greenberg, Ezekiel 21-37, 742; Robson, Word and Spirit, 109-111).

44 Por. Block, „The Prophet of the Spirit”, 32-33. Block identyfikuje podobną dialektykę znaczenia rûa ḥ (strony świata - wiatr) jeszcze w Ez 5,2; 12,14; 17,21. 
Po drugie, hārûa ḥ pozostaje rzeczywistością zewnętrzną wobec Boga, skoro prorok otrzymuje polecenie wezwania tego ducha z czterech wiatrów/stron $(37,9)$. Podmiotowość hārûa ḥ jest sugerowana również przez polecenie, jakie Bóg wydaje mu za pośrednictwem Ezechiela: to nie Bóg „tchnie” hārûa ḥ w pozostające bez życia ciała, lecz to sam hārûa ha ma "tchnąć w tych pobitych, by ożyli” (w. 9). Uzasadnione jest zatem mówienie o hārûa h jako hipostazie Boga: pozostając ściśle związany z Bogiem, posiada on pewną podmiotowość i odrębność, o czym stanowi zadanie, jakie ma do zrealizowania.

Po trzecie, ożywiające działanie hārûa ḥ wobec domu Izraela, metaforyzowanego wyschniętymi kościami, jest przedstawione w wizji jako akt nowego stworzenia. Ta interpretacja nie wynika tylko $\mathrm{z}$,naśladowania paradygmatu stworzenia przez Jahwe 'ādām ${ }^{\prime \prime} 4$. Przedstawione w w. 10 ożywiające działanie ducha Jahwe jest analogiczne do działania wobec Ezechiela podczas wizji powołaniowej $(2,2)$ : w obu przypadkach

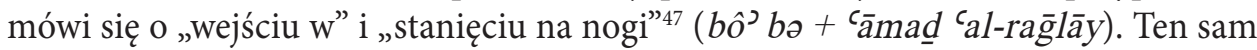
duch Jahwe, który jest działający w proroku, ożywi tych, do których prorok jest posłany.

Ostateczna identyfikacja hārûa ḥ ożywiającego przyobleczone w ciało wyschnięte kości następuje w finalnym zdaniu wyjaśniającym wizję: „dam mojego ducha (rûhîi) w was i ożyjecie" (Ez 37,14). Użycie terminu rûhî jednoznacznie potwierdza teologiczne znaczenie analizowanego rzeczownika, jednakże równocześnie wpisuje się w koncepcję „rozwijającego się symbolu”, który wymaga odniesienia się do identycznego określenia Bożego ducha w Ez 36,27 i 39,29. To pozwoli na wydobycie jeszcze głębszego znaczenia wizji ożywienia wyschniętych kości.

\subsection{Nowy lud przymierza}

Kluczem do wizji wyschniętych kości jest zdanie identyfikujące je $\mathrm{z}$ „całym domem Izraela" (Ez 37,11a). Ożywienie narodu jest zapowiadane jako powrót $\mathrm{z}$ wygnania do ziemi obiecanej (w. 12). Zamiast klasycznej triady, opisującej w Księdze Ezechiela proces powrotu ${ }^{48}$, zostaje przywołany ostatni etap: wprowadzenie do ziemi, zapisane

46 Block, The Book of Ezekiel. Chapters 25-49, 379.

47 W wymienionych tekstach Księgi Ezechiela zachodzi pewna różnica: w 2,2 i 3,24 podmiotem czasownika ‘āma d w Hi jest duch Jahwe, natomiast w 37,10 podmiotem tego czasownika w Qal są już ożywione ciała pobitych. Ta zmiana może być podyktowana inną sytuacją Ezechiela i zrekonstruowanych ciał pobitych. Celem powstania na nogi proroka jest wejście w komunikację z Bogiem, co jest możliwe tylko dzięki duchowi Jahwe. W przypadku ciał pobitych, jeśli przyjąć kontekst bitewny, ich powstanie na nogi nie wiąże się ze stanięciem wobec Jahwe, lecz ma na celu powstanie do konfrontacji z przeciwnikiem na polu walki (por. najazd wojsk Goga w Ez 38-39). Por. Robson, Word and Spirit, 239, przyp. 146.

48 Pierwszą czynnością Boga jest zgromadzenie rozproszonych z wygnania (por. qāba 36,24; 37,21), drugą - wyprowadzeniu ich z rozproszenia (por. yāṣa $\bar{a}^{-}$w Hi w 34,13; lāḳạ̣ w 36,24; 37,21), zaś trzecią - wprowadzenie do ziemi (por. bồ w Hi w 34,13; 36,24; 37,12.21). Por. Pikor, „Prorocka interpretacja", 50. 
czasownikiem $b \hat{o}^{\supset} \mathrm{w} H i$ (w. 12b). Ze strony Boga pojawia się za to dodatkowa czynność, która przypieczętowuje powrót: Bóg „osadzi [Izraelitów] w ich ziemi” (nāwah w Hi w w. 14b). Pomiędzy tymi dwoma momentami odrodzenia ludu w wymiarze materialnym znajduje się inny akt rewitalizujący Izrael, tym razem w wymiarze wewnętrznym: Bóg „da w nich swego ducha [rûhị̂]” (w. 14a). Taka sekwencja zdarzeń sugeruje, że zamieszkanie w ziemi obiecanej przez Izrael wymaga wcześniejszego aktu stworzenia nowego ludu przymierza. Podstawą nowej wspólnoty przymierza jest wewnętrzne odrodzenie Izraela, które zostaje określone wprost jako „nowe” przez dar „nowego serca” $(36,26)$ i „nowego ducha” $(11,19 ; 36,26)$. Nie jest ono możliwe mocą człowieka, mimo że Bóg wzywa lud do „uczynienia sobie nowego serca i nowego ducha” (18,31). Potrzeba Bożej interwencji, która przyniesie „transplantację" serca (w miejsce "serca kamiennego" Bóg zapowiada "serce z ciała”; 11,19; 36,26), zaś „w ich wnętrze da swego ducha [rûhị̂]” $(36,27 \mathrm{a})^{49}$.

Sekwencję zdarzeń zapisaną $\mathrm{w}$ interpretacji wizji wyschniętych kości $(37,12-14)$ potwierdza struktura proroctwa o nowym przymierzu w 36,24-28 (por. 11,16-20), w którego centrum znajduje się dar nowego serca i nowego ducha: powrót z wygnania (w. 24) - oczyszczenie z nieczystości (w. 25) - dar nowego serca i nowego ducha (ww. 26-27a) - uzdolnienie do zachowywania Prawa (w. 27b) - zamieszkanie w ziemi (w. 28). Akt nowego stworzenia Izraela jest zatem niezbędny nie tylko po to, by mógł on wrócić do swojej ziemi, ale przede wszystkim po to, by mógł w niej na stałe zamieszkać jako lud przymierza. By tak się stało, Izrael musi być posłuszny Prawu, gdyż wypełnianie go stanowi gwarancję życiodajnej relacji z Jahwe (por. 18,9.17; 20,11.13.21;33,15). Jednakże podstawą trwania tej nowej wspólnoty przymierza będzie samoudzielenie się Boga w „swoim duchu” (36,27a).

Zapowiadany w ww. 26-27a akt stworzenia koresponduje w pewnym sensie z wizją ożywienia wyschniętych kości, która metaforycznie kreśli powrót do życia Izraela $\mathrm{w}$ dwóch etapach: najpierw przywrócenie ciała, a następnie udzielenie mu Bożego ducha ${ }^{50}$. W obietnicy nowego przymierza transformacja dotknie najpierw ciała. W kontekście Księgi Ezechiela „serce kamienne” nawiązuje do motywu „serca zatwardziałego", które w mowie powołującej Ezechiela na proroka zostało wskazane przez Boga jako źródło buntowniczego charakteru Izraela (por. 2,4; 3,7). Takie serce nie tylko jest niesłuchające i nieposłuszne wobec słowa Bożego, ale też jest „sercem wiarołomnym”, które nie pamięta o Jahwe (por. 6,9) i zwraca się ku bożkom (por. 14,3.4.7; 20,16). Takie serce jest „idolatryczne” również w tym sensie, że jest „martwe”, podobnie jak serce bożków, za którymi podąża $a^{51}$. O przemianie wewnętrznej Izraela będzie stanowić dar „serca z ciała” (36,26b). Nowe serce jawi się jako serce właściwe ludzkiej naturze (,z ciała”), wpisujące się w pierwotny akt stworzenia.

49 Por. analizę tych tekstów w: Pikor, The Land of Israel, 138-142.

50 Por. Granados García, La nueva alianza, 170-173.

51 Por. Kutsko, Between Heaven and Earth, 128-129; Granados García, La nueva alianza, 168-169. 
Dzięki „sercu z ciała” odzyska człowiek prawdziwą zdolność odczuwania, poznawania i wybierania tego, co jest dobre, czyli służy jego życiu.

W zapowiedzi nowego przymierza nic nie mówi się o wymianie ducha ludzkiego na Bożego. Biorąc pod uwagę pesymizm i beznadzieję paraliżujące serca Izraelitów po upadku Jerozolimy (por. ich wypowiedzi w 33,10; 37,11), można stwierdzić, iż „ich duch całkowicie osłabł” $(21,12)$ i potrzebuje życiodajnego impulsu Bożego. Bóg, „dając w ich wnętrze swego ducha” (36,27a), uzdolni ich „serce z ciała” do trwania w życiodajnym przymierzu przez wierne i stałe zachowywanie Bożych praw (w. w. 27b). Stałośći wierność „, serca z ciała” będzie gwarantowana Bożym duchem, który stworzy na nowo ludzką wolę, zdolną do posłuszeństwa wobec Boga i Jego słowa.

Dar, jaki Bóg uczyni Izraelowi ze „swego ducha”, nie będzie aktem jednorazowym. Trzecie z Ezechielowych proroctw o Bożym duchu, identyfikowanym jako rûḥ̂ $(39,29)$, czyni obietnicę stałej już jego obecności w ludzie przymierza, co czyni Izraela podobnym do Ezechiela w jego stałym doświadczeniu Bożego ducha od momentu powołania.

Zapowiedź wylania Bożego ducha w 39,29 koresponduje z sekwencją wydarzeń zapowiadających ten sam dar w 36,27 i 37,14. We wszystkich tych proroctwach Bóg obiecuje dać swego ducha Izraelitom po wcześniejszym zebraniu ich z wygnania i przyprowadzeniu do ziemi obiecanej (por. 36,24; 37,12-13; 39,27-28). Zakładając model interpretacji rû́ạ jako „rozwijającego się symbolu”, metafora akwatyczna w 39,29 ukazuje nowy aspekt stwórczego działania ducha Jahwe wobec Izraela.

Po pierwsze, wybór czasownika šāpak („,wylać”) sugeruje obfitość Bożego ducha, bezgraniczność tego daru dla ludu. Mimo że mówi się o wylaniu go „na” ( $\left.{ }^{c} a l\right)$ Izraelitów, a nie udzieleniu go do ich wnętrza (jak w przypadku zapowiedzi w 36,27 i 37,14), to metaforyzacja rû́a jako wody zakłada nie tylko wniknięcie go w ich wnętrze, czy wręcz „nasiąknięcie” nim, ale też suponuje ożywiające działanie rûa ḥ na podobieństwo wody gwarantującej życie.

Po drugie, użycie czasownika šāpak w tej obietnicy stanowi odwrócenie typowego dla Księgi Ezechiela zwrotu, w którym Bóg mówi o „wylaniu” (šāpak gniewu $\left(h \bar{e} \bar{m} \bar{a}^{h}\right)$ lub oburzenia (za $\left.{ }^{\complement} a m\right)$ na dom Izraela z powodu ich grzechów i nieczystości5 ${ }^{52}$. „Wylanie rûḥ̣̂” będzie zatem odwróceniem wylania Bożego gniewu i oburzenia, co stanie się możliwe nie tylko dzięki oczyszczeniu Izraela z jego grzechów (por. 36,25), ale również uzdolnieniu go, dzięki darowi „nowego ducha”, do życia Bożym prawem (por. 36,27b) ${ }^{53}$.

Po trzecie, od strony składniowej obietnica wylania Bożego ducha w 39,29, poprzedzona zaimkiem 'ăšer, stanowi zdanie podrzędne względem zdania nadrzędnego, w którym Bóg zapowiada, iż „nie będzie już więcej ukrywał swojej twarz od nich”.

\footnotetext{
52 Wyrażenie „wylać gniew” w Ez 7,8; 9,8; 14,19; 20,8.13.21.33.34; 22,22; 30,15; 36,18, zaś „wylać oburzenie” w 21,36; 22,31 .

53 Por. De Vries, „The Relationship”, 340.
} 
בăšer jest tu tłumaczone albo jako zaimek wprowadzający zdanie podrzędne czasowe („kiedy”), albo jako zaimek wprowadzający zdanie podrzędne przyczynowe („ponieważ, gdyż” $)^{54}$. Niezależnie od interpretacji ’̌ăšer, wylanie przez Boga swego ducha (rûhîi) będzie skutkowało tym, iż Boże oblicze ( $p a \bar{n} n \hat{m})$ nie pozostanie więcej odwrócone od odrodzonego ludu przymierza. W kilku tekstach Biblii Hebrajskiej - jak było to już powiedziane - pānîm, jako wyraz Bożej obecności, pozostaje ściśle związane z r $\hat{u}^{a} h$ Boga (por. Ps 51,13; 104,29-30; 139,7; Iz 63,10-14). W tym kontekście można odczytać proroctwo Ez 39,29 jako coś więcej niż tylko zapowiedź obecności Boga pośród swego ludu, która zagwarantuje mu pomyślne i bezpieczne zamieszkanie w ziemi obiecanej. Poprzez dar Bożego ducha, który dokona wewnętrznej transformacji Izraela, nowy lud przymierza będzie mógł doświadczać już na stałe w swoim wnętrzu tej ożywiającej obecności Boga ${ }^{55}$.

Lektura intertekstualna trzech zapowiedzi Bożego ducha (rûḥ̂i) w Ez 36,27; 37,14 i 39,29 pozwala na jeszcze jeden wniosek związany z doświadczeniem Bożego ducha przez Ezechiela. Ezechiel staje się prorokiem dzięki stwórczemu aktowi Bożego r $\hat{u}^{a} h \underline{\varphi}$ $(2,2)$. W kontekście swego powołania i posłania do domu Izraela Ezechiel słyszy zapewnienie, iż jego słuchacze „poznają, że jest prorok pośrodku nich” (2,5; por. 33,33). Ta zaskakująca zmiana w typowej dla Księgi Ezechiela formule poznania Jahwe nawiązuje do tradycji o Eliaszu, w której „poznanie, iż jest prorok pośrodku Izraela” $(2 \mathrm{Krl} 5,8)$ jest równoznaczne $\mathrm{z}$ „poznaniem, że nie ma Boga w świecie poza Izraelem" $(5,15)^{56}$. Prorok Ezechiel, dzięki działaniu ducha Jahwe, objawia sobą, swoimi słowami i czynami obecność Boga pośród swego ludu. Przez dar Bożego ducha odrodzony Izrael otrzymuje misję prorocką w świecie, by jako lud przymierza objawiać w nim obecność Boga.

Księga Ezechiela wykorzystuje wieloznaczność rzeczownika rûạ̣ dla ukazania różnorodnej obecności i aktywności Boga w świecie. Na pierwszym miejscu ma ona charakter stwórczy, co pokazała analiza dynamiki działania Bożego rû̉ ḥ w opowiadaniu o powołaniu Ezechiela i w wizji ożywienia wyschniętych kości: Ezechiel zostaje stworzony jako prorok, zaś Izrael, będący na wygnaniu, zostanie stworzony na nowo jako lud przymierza. Osobiste doświadczenie Bożego rûa ḥ przez Ezechiela, które staje się zasadą jego komunikacji prorockiej, czyni wiarygodnym jego słowo obietnicy Bożego rûa ḥ dla Izraela. W istocie sam Ezechiel jako prorok jest słowem zapowiadającym stworzenie nowego ludu przymierza, który dzięki Bożemu rû́ạ bę-

\footnotetext{
54 Por. zestawienie odpowiednich komentarzy w: Wong, „The Masoretic and Septuagint Texts”, 142-143.

55 De Vries („The Relationship”, 342) w tym kontekście mówi o duchu Jahwe jako hipostazie: „Ponieważ duch Jahwe jest manifestacją Jego istoty, możemy powiedzieć, że w przyszłości Jahwe będzie obecny w sercach Izraelitów na sposób hipostazy. Obecność Jahwe w sercach swego ludu poprzez dar swego ducha jest odpowiednikiem Jego manifestacji poprzez chwałę w przyszłej świątyni”. 
dzie trwał w życiodajnej relacji z Jahwe w ziemi obiecanej. Przedstawiony w Księdze Ezechiela sposób aktywności rûa ḥ pozwala widzieć w nim hipostazę Boga: rûa ḥ, pochodząc od Boga, uobecnia Jego moc i pozostaje wyrazem Jego woli, dokonując i kontynuując dzieło stworzenia.

\section{Bibliografia}

Allen, L.C., Ezekiel 1-19 (WBC 28; Dallas, TX: Word Books 1994).

Allen, L.C., Ezekiel 20-48 (WBC 29, Dallas, TX: Word Books 1990).

Block, D.I., The Book of Ezekiel. Chapters 1-24 (NICOT; Grand Rapids, MI - Cambridge: Eerdmans 1997).

Block, D.I., The Book of Ezekiel. Chapters 25-48 (NICOT; Grand Rapids, MI - Cambridge: Eerdmans 1998).

Block, D.I., „The Prophet of the Spirit. The Use of the רוח in the Book of Ezekiel”, Journal of the Evangelical Theology Society 32 (1989) 27-49.

Boadt, L., „The Function of the Salvation Oracles in Ezekiel 33 to 37”, Hebrew Annual Review12 (1990) 1-21.

Bossu, N., Une prophétie au fil de la tradition. Loracle des ossements desséchés (Ez 37,1-14) et ses relectures chrétiennes, entre herméneutique et théologie (EtB 69; Paris: Gabalda et Cie 2015).

Carley, K.W., Ezechiel among the Prophets. A Study of Ezechiel's Place in Prophetic Tradition (SBT 31; London: SCM 1975).

De Vries, P., „The Relationship between the Glory of YHWH and the Spirit of YHWH in Ezekiel 33-48", Old Testament Essays 28 (2015) 326-360.

Eichrodt, W., Ezekiel. A Commentary, wyd. 5 (OTL; London: SCM Press 1996).

Fishbane, M., Biblical Interpretation in Ancient Israel (Oxford: Clarendon 1985).

Graffy, A., A Prophet Confronts His People (AnBib 104; Rome: Biblical Institute Press 1984).

Granados García, C., La nueva alianza como recreación. Estudio exegético de Ez 36:16-38 (AnBib 184; Roma: Gregorian \& Biblical Press 2010).

Greenberg, M., Ezekiel 1-20. A New Translation with Introduction and Commentary (AB 22; Garden City, NY: Doubleday 1983).

Greenberg, M., Ezekiel 21-37. A New Translation with Introduction and Commentary (AB 22A; Garden City, NY: Doubleday 1997).

Fox, M.V., „The Rhetoric of Ezekiel's Vision of the Valley of the Bones”, Hebrew Union College Annual 51 (1980) 1-15.

Hals, R.M., Ezekiel (FOTL 19; Grand Rapids, MI: Eerdmans 1989).

Hiebel, J.M., Ezekiel's Vision Accounts as Interrelated Narratives. A Redaction-Critical and Theological Study (BZAW 475; Berlin - Boston, MA: De Gruyter 2015).

Homerski, J., Księga Ezechiela. Wstęp - przekład z oryginatu - komentarz - ekskursy (PŚST 11/1; Poznań: Pallotinum 2013).

Hosch, H.E., „Rûah in the Book of Ezekiel. A Textlinguistic Analysis”, Journal of Translation and Textlinguistics 14 (2002) 77-125. 


\section{WOJCIECH PIKOR}

Hossfeld, F.-L., Untersuchungen zu Komposition und Theologie des Ezechielbuches (FzB 20; Würzburg: Echter 1977).

Hubmann, F.D., „Ezechiel 37,1-14 in der neueren Forschung”, Auf den Spuren der schriftgelehrten Weisen. Festschrift für Johannes Marböc (red. I. Fischer - U. Rapp - J. Schiller) (BZAW 331; Berlin - New York: de Gruyter 2003) 111-128.

Joüon, P. - Muraoka, T., A Grammar of Biblical Hebrew (Subsidia biblica 27; Roma: Pontificio Istituto Biblico 2006).

Joyce, P.M., Ezekiel. A Commentary (LHB/OTS 482; New York - London: T \& T Clark 2007).

Kinlaw, P.E., „From Death to Life. The Expanding רוח in Ezekiel”, Perspectives in Religious Studies 30 (2003) 161-172.

Klein, A., Schriftauslegung im Ezechielbuch. Redaktionsgeschichtliche Untersuchungen zu Ez 34-39 (BZAW 391; Berlin - New York, NY: de Gruyter 2008).

Konkel, M., „The Vision of the Dry Bones (Ezek 37.1-14). Resurrection, restoration or what?”, Ezekiel. Current Debates and Future Directions (W.A. Tooman - P. Barter) (FAT 112; Tübingen: Mohr Siebeck 2017) 107-119.

Kutsko, J.F., Between Heaven and Earth. Divine Presence and Absence in the Book of Ezekiel (BJSt 7; Winona Lake, IN: Eisenbrauns 2000).

Lemański, J., „Sprawisz, abym ożył (Ps 71,20b)”. Źródła nadziei na zmartwychwstanie w Starym Testamencie (Szczecin: Wydawnictwo Naukowe Uniwersytetu Szczecińskiego 2004).

MacDonald, N., „The Spirit of YHWH. An Overlooked Conceptualization of Divine Presence in the Persian Period", Divine Presence and Absence in Exilic and Post-Exilic Judaism. Studies of the Sofja Kovalevskaja Research Group on Early Jewish Monotheism (red. N. MacDonald - I.J. de Hulster) (FAT 2/61; Tübingen: Mohr Siebeck 2013) II, 95-119.

Pikor, W., La comunicazione profetica alla luce di Ez 2-3 (TG.ST 88; Roma: Editrice Pontificia Università Gregoriana 2002).

Pikor, W., „Prorocka interpretacja exodusu. II. Ezechiel, Deutero-Izajasz”, Biblica et Patristica Thoruniensia 7/4 (2014) 47-64.

Pikor, W., „Retoryka Ezechielowej wizji Chwały Jahwe (Ez 1)”, Język Biblii. Od stuchania do rozumienia (red. W. Pikor) (Studia Biblica 11; Kielce: Jedność 2005) 117-150.

Pikor, W., The Land of Israel in the Book of Ezekiel (LHB/OTS 667; New York - London: T \& T Clark 2018).

Pohlmann, K.-F., Der Prophet Hesekiel/Ezechiel. Kapitel 20-48 (ATD 22.2, Göttingen: Vandenhoeck \& Ruprecht 2001).

Robson, J., Word and Spirit in Ezekiel (LHB/OTS 447; New York, NY - London: T \& T Clark 2006).

Sedlmeier, F., Das Buch Ezechiel. Kapitel 1-24 (NSK.AT 21/1; Stuttgart: Katholisches Bibelwerk 2002).

Sedlmeier, F., Das Buch Ezechiel. Kapitel 25-48 (NSK.AT 21/2; Stuttgart: Katholisches Bibelwerk 2013).

Strong, J.T. „God's Kābôd. The Presence of Yahweh in the Book of Ezekiel”, The Book of Ezekiel. Theological and Anthropological Perspectives (red. M.S. Odell - J.T. Strong) (SBL.SymS 9; Atlanta, GA: Society of Biblical Literature 2000) 69-95.

Waltke, B.K. - O'Connor, M., An Introduction to Biblical Hebrew Syntax (Winona Lake, IN: Eisenbrauns 1990). 
Wong, K.L., „The Masoretic and Septuagint Texts of Ezekiel 39,21-29”, Epheremides Theologicae Lovanienses 78 (2002) 130-147.

Woodhouse, J., „The 'Spirit' in the Book of Ezekiel”, Spirit of the Living God (red. B.G. Webb) (Exploration 5; Sydney: Lancer 1991) I, 1-22.

Wright, T.J., „The Concept of Ruach in Ezekiel 37”, Seeing Signals, Readings Signs. The Art of Exegesis. Studies in Honour of Antony F. Campbell, SJ for His Seventieth Birthday (red. M.A. O’Brien - H.N. Wallace) (London - New York: T \& T Clark 2004) 142-158.

Yadin, A., „Qôl as Hypostasis in the Hebrew Bible”, Journal of Biblical Literature 122 (2003) 601-626.

Zimmerli, W., Ezekiel. I. A Commentary on the Book of the Prophet Ezekiel. Chapters 1-24 (Hermeneia; Philadelphia: Fortress 1979).

Zimmerli, W., Ezekiel. II. A Commentary on the Book of the Prophet Ezekiel. Chapters 25-48 (Hermeneia; Philadelphia: Fortress 1983). 
